\title{
Role Performances of Agricultural Extension Professionals - A Study in Odisha
}

\author{
K. K. Behera* and R.N. Das \\ Department of Extension Education, College of Agriculture, OUAT, Bhubaneswar, India \\ *Corresponding author
}

Keywords

Role performance,

Extension

Professionals,

Technology

transfer, Farmers

Article Info

Accepted:

20 July 2020

Available Online:

10 August 2020

\section{A B S T R A C T}

Role performance of the Agricultural extension professionals are much required for effective technology transfer and continued adoption by the farmers. A study conducted with 182 Agricultural extension professionals revealed that the respondents had performed better on developing technical competency, communication system, planning, programme implementation and capacity building of the farmers in comparison to community organization and marketing of the produce. Liasoning for the community storage, marketing organizations and traders for timely procurement of the produce, preparing teaching aids while organizing training, organizing campaigns on the specific problems, economic use of natural resources, exposure visit to develop confidence of the farmers, liasoning with credit institutions to finance farmers and organizing farmers for better approach have to be further strengthened in their role performance for the betterment of the farmers.

\section{Introduction}

Extension is a human process in which technical information is used to help rural people in achieving their potential (Tiraieyari, et al., 2011). A holistic approach to Agricultural extension today goes beyond technology transfer for major crops, livestock production and other related activities. It also includes goals for the human capital development in terms of enhancing the management and technical skills of farm households relating to production and postharvest, sustainable natural resource management, nutrition, leadership and organization skills in addition to developing producer groups (Swanson, 2006). Agricultural extension also facilitates problem solving creating links to market and other players in the Agricultural value chain as well as providing access to information, skills and technologies (Cooper and Graham, 2001). Therefore, role performances of the extension professionals are many folded to satisfy the 
needs and requirements of the farming community.

An attempt was therefore made to analyze the role performance of the Agricultural extension professionals for the improvement of the farming community.

\section{Materials and Methods}

The study was undertaken in Odisha state during 2018. Extension professionals working in the state department of Agriculture and Horticulture were chosen as the respondents for the study. The questionnaire was developed on the basis of pilot study which was also pre-tested and finalized. The same was mailed to 325 extension professionals where only 182 extension professionals of Agriculture and Horticulture had responded by sending the filled-in questionnaire. Working environment, technical competency, communication, planning, programme implementation, capacity building, monitoring and supervision, marketing as well as reporting were selected as the variables. The data collected on scale point of always, frequently, some times and never were analyzed with the score value of 4, 3,2 and 1 respectively. Statistical tools such as mean score, gap percentage and multiple regression analysis were employed to reveal the results.

\section{Results and Discussion}

The state department of Agriculture has several well defined and specific objectives being ventilated to the extension personnel to work accordingly. Creating good working environment facilities effective transfer of technologies for the betterment of the farming community. As observed from Table-1, the respondents had better role performances on assuming responsibility to perform the assigned work, interest for Information Communication Technology (ICT) facility and to some extent consciousness to collect need based information as well as establishing strong linkages with department officials. The extension professionals should feel satisfaction on every day's work, getting pleasure in work instead of feeling as burden, feeling proud and cheerful in duty, maintaining office with educational importance and liasoning with developmental departments for resource mobilization to justify their job performance. But, poor performances observed on these aspects need all possible remedial measures by the executives of the concerned organization to create good working environment for the extension professionals to serve better for the farming community.

The extension professionals should have technical competency in dissemination of need based technology and develop capability of the farmers for adoption. The extension professionals should therefore update with the latest information available and screen out the information feasible for the operational area, participating fully in various educational activities to abreast with technological developments as well as discussing with colleagues for sharing of experience and information exchange which were lacking and needs to be strengthened by the executives of the organization (Table-2). However; better performances were observed on regular contact with scientists and experts to seek solutions to the problems faced, conducting field trials to assess performance and discussing with experts about the performances of new technologies feasible to their operational area which are equally essential for the development of the farming community.

Effective dissemination of technology is also equally important in developing interest among the farmers in adoption of technologies. 
Table.1 Role performance on working environment

\begin{tabular}{|c|l|c|c|}
\hline $\begin{array}{c}\text { SI. } \\
\text { No. }\end{array}$ & \multicolumn{1}{|c|}{ Expectation } & $\begin{array}{c}\text { Mean } \\
\text { Score }\end{array}$ & $\begin{array}{c}\text { Gap } \\
(\mathbf{\%})\end{array}$ \\
\hline $\mathbf{1 .}$ & Assume responsibility to perform the work assigned & 3.560 & 11.00 \\
\hline $\mathbf{2 .}$ & Feel proud and cheerful in duty & 3.220 & 19.50 \\
\hline $\mathbf{3 .}$ & Conscious to collect need based information & 3.456 & 13.60 \\
\hline $\mathbf{4 .}$ & Liasoning with developmental departments for assistance & 3.291 & 17.73 \\
\hline $\mathbf{5 .}$ & Establishing strong linkages with department officials & 3.401 & 14.98 \\
\hline $\mathbf{6 .}$ & Maintain office with educational importance & 3.275 & 18.13 \\
\hline $\mathbf{7 .}$ & Interest for ICT facilities & 3.500 & 12.50 \\
\hline $\mathbf{8 .}$ & Feel satisfaction with every day's work performed & 3.187 & 20.33 \\
\hline $\mathbf{9 .}$ & Getting pleasure in work rather feeling as burden & 3.187 & 20.33 \\
\hline
\end{tabular}

(Maximum obtainable score -4 )

Table.2 Role performance on technical competency

\begin{tabular}{|c|c|c|c|}
\hline $\begin{array}{c}\text { Sl. } \\
\text { No. }\end{array}$ & Performance & $\begin{array}{l}\text { Mean } \\
\text { Score }\end{array}$ & $\begin{array}{l}\text { Gap } \\
(\%)\end{array}$ \\
\hline 1. & Updating latest information from different sources & 3.357 & 16.08 \\
\hline 2. & Participate fully in educational activities & 3.214 & 19.65 \\
\hline 3. & Screening technical information feasible to the area & 3.186 & 20.35 \\
\hline 4. & $\begin{array}{l}\text { Regular contact with scientists and experts to solve } \\
\text { problems }\end{array}$ & 2.995 & 25.13 \\
\hline 5. & Discussed with colleagues for information exchange & 3.269 & 18.28 \\
\hline 6. & Conducting field trials to assess performance & 2.824 & 29.40 \\
\hline 7. & $\begin{array}{l}\text { Discussed with experts about the performances of new } \\
\text { technologies }\end{array}$ & 2.962 & 25.95 \\
\hline
\end{tabular}

(Maximum obtainable score -4)

Table.3 Role performance on communication

\begin{tabular}{|c|l|c|c|}
\hline $\begin{array}{c}\text { Sl. } \\
\text { No. }\end{array}$ & \multicolumn{1}{|c|}{ Performance } & $\begin{array}{c}\text { Mean } \\
\text { Score }\end{array}$ & $\begin{array}{c}\text { Gap } \\
(\mathbf{\%})\end{array}$ \\
\hline $\mathbf{1 .}$ & Discussing with experts in formulating need based messages & 3.000 & 25.00 \\
\hline $\mathbf{2 .}$ & Preparing and distributing farm literatures for reference & 3.028 & 24.30 \\
\hline $\mathbf{3 .}$ & Keeping close contact with farm leaders for message transfer & 3.258 & 18.55 \\
\hline $\mathbf{4 .}$ & Preparing teaching aids relevant to the area & 2.813 & 29.68 \\
\hline $\mathbf{5 .}$ & Giving wide publicity on implemented programmes & 3.115 & 22.13 \\
\hline 6. & Providing spot solutions on field problems & 3.308 & 17.30 \\
\hline 7. & Put thrust on non-responsive farmer's motive & 2.896 & 27.60 \\
\hline
\end{tabular}

(Maximum obtainable score -4 ) 
Table.4 Role performance in planning

\begin{tabular}{|c|l|c|c|}
\hline $\begin{array}{c}\text { Sl. } \\
\text { No. }\end{array}$ & \multicolumn{1}{|c|}{ Performance } & $\begin{array}{c}\text { Mean } \\
\text { Score }\end{array}$ & $\begin{array}{c}\text { Gap } \\
\mathbf{( \% )}\end{array}$ \\
\hline 1. & Participatory in problem diagnosis & 3.247 & 18.83 \\
\hline 2. & Assessing root cause of the problems & 3.286 & 17.85 \\
\hline 3. & Developing programmes involving farmers & 3.000 & 25.00 \\
\hline 4. & $\begin{array}{l}\text { Selecting responsive farmers for field trial and } \\
\text { demonstrations. }\end{array}$ & 3.297 & 17.58 \\
\hline 5. & Pre-arrangement of inputs and materials & 3.247 & 18.83 \\
\hline 6. & Emphasis on conservation of soil and moisture & 3.011 & 24.73 \\
\hline 7. & Popularization of implements and machineries & 3.231 & 19.23 \\
\hline
\end{tabular}

(Maximum obtainable score -4 )

Table.5 Role performances on programme implementation

\begin{tabular}{|c|l|c|c|}
\hline $\begin{array}{r}\text { Sl. } \\
\text { No. }\end{array}$ & \multicolumn{1}{|c|}{ Performance } & $\begin{array}{c}\text { Mean } \\
\text { Score }\end{array}$ & $\begin{array}{c}\text { Gap } \\
\mathbf{( \% )}\end{array}$ \\
\hline 1. & Involving farmers fully in implementation & 3.258 & 18.55 \\
\hline 2. & Timely use of inputs and materials & 3.214 & 19.65 \\
\hline 3. & Immediate action on field problems & 3.357 & 16.08 \\
\hline 4. & Economic use of natural resources & 2.824 & 29.40 \\
\hline 5. & Organising field days and method demonstrations & 3.231 & 19.23 \\
\hline 6. & Contingent measures in adverse situations & 2.967 & 25.83 \\
\hline 7. & Participatory evaluation of results & 2.995 & 25.13 \\
\hline
\end{tabular}

(Maximum obtainable score -4 )

Table.6 Role performance on capacity building of the farmers

\begin{tabular}{|c|l|c|c|}
\hline $\begin{array}{c}\text { Sl. } \\
\text { No. }\end{array}$ & \multicolumn{1}{|c|}{ Performance } & $\begin{array}{c}\text { Mean } \\
\text { Score }\end{array}$ & $\begin{array}{c}\text { Gap } \\
(\mathbf{\%})\end{array}$ \\
\hline 1. & Conducting training for knowledge and skill competency & 3.258 & 18.55 \\
\hline 2. & Organising exhibition for technology transfer & 2.896 & 27.60 \\
\hline 3. & Exposure visit to develop confidence of the farmers & 2.857 & 28.58 \\
\hline 4. & Organising field days to prove the technology performance & 3.104 & 22.40 \\
\hline 5. & Publish literature in local language for use of the farmers & 3.033 & 24.18 \\
\hline 6. & Linking farmers with experts and scientists for knowledge upgradation & 2.956 & 26.10 \\
\hline 7. & Organising campaign on specific problems & 2.813 & 29.68 \\
\hline 8. & Motivating farmers for documentation and evaluation of activities & 3.115 & 22.13 \\
\hline
\end{tabular}

(Maximum obtainable score -4 ) 
Table.7 Role performances on community organization

\begin{tabular}{|c|l|c|c|}
\hline $\begin{array}{c}\text { Sl. } \\
\text { No. }\end{array}$ & \multicolumn{1}{|c|}{ Performance } & $\begin{array}{c}\text { Mean } \\
\text { Score }\end{array}$ & $\begin{array}{c}\text { Gap } \\
(\mathbf{\%})\end{array}$ \\
\hline 1. & Organize farmers and form homogenous groups & 2.956 & 26.10 \\
\hline 2. & Motivate for cluster approach & 3.302 & 17.45 \\
\hline 3. & Guide for commercial cultivation & 3.269 & 18.28 \\
\hline 4. & Liasoning with credit institution for finance & 2.857 & 28.58 \\
\hline 5. & Incorporate traditional wisdom in the programmes & 2.978 & 25.55 \\
\hline 6. & Suggesting income generating activities for women & 3.242 & 18.95 \\
\hline 7. & Facilitating conflict resolution & 2.923 & 26.93 \\
\hline 8. & Ensure cooperation and coordination among villagers & 3.319 & 17.03 \\
\hline 9. & Motivate youth for custom hiring service & 3.006 & 24.85 \\
\hline
\end{tabular}

(Maximum obtainable score -4 )

Table.8 Role performance on marketing of the produce

\begin{tabular}{|c|l|c|c|}
\hline $\begin{array}{r}\text { Sl. } \\
\text { No. }\end{array}$ & \multicolumn{1}{|c|}{ Performance } & $\begin{array}{c}\text { Mean } \\
\text { Score }\end{array}$ & $\begin{array}{c}\text { Gap } \\
(\mathbf{\%})\end{array}$ \\
\hline 1. & Guiding for quality production & 3.445 & 13.88 \\
\hline 2. & Provide expertise for value addition & 3.093 & 22.68 \\
\hline 3. & Facilitating for proper storage & 3.099 & 22.53 \\
\hline 4. & Guide to collect market information & 3.044 & 23.90 \\
\hline 5. & Coordinate and liason with marketing organisations & 2.676 & 33.10 \\
\hline 6. & Liasoning with traders for timely procurement & 2.692 & 32.70 \\
\hline 7. & Liasoning with district authority for community storage & 2.615 & 24.63 \\
\hline
\end{tabular}

(Maximum obtainable score -4)

Table.9 Regression analysis of socio-economic attributes on role performances

\begin{tabular}{|c|l|c|c|c|c|c|c|}
\hline \multirow{2}{*}{$\begin{array}{c}\text { Sl. } \\
\text { No. }\end{array}$} & \multirow{2}{*}{ Attribute } & \multicolumn{2}{|c|}{$\begin{array}{c}\text { Unstandardized } \\
\text { co-efficient }\end{array}$} & \multicolumn{2}{|c|}{$\begin{array}{c}\text { Standardized co- } \\
\text { efficient }\end{array}$} & \multirow{2}{*}{ 't' } \\
value & \multirow{2}{*}{ Probability } \\
\cline { 3 - 7 } & & Beta & $\begin{array}{c}\text { Std. } \\
\text { error }\end{array}$ & Beta & $\begin{array}{c}\text { Std. } \\
\text { error }\end{array}$ & & \\
\hline 1. & Age & 18.288 & 5.856 & 0.439 & 0.070 & 3.123 & 0.002 \\
\hline 2. & Qualification & -5.108 & 4.726 & -0.077 & 0.140 & -1.081 & 0.281 \\
\hline 3. & Experience & -15.189 & 3.492 & -0.607 & 0.071 & -4.349 & 0.000 \\
\hline 4. & Background & -0.778 & 3.165 & -0.018 & 0.140 & -0.246 & 0.806 \\
\hline 5. & Training & -6.550 & 2.848 & -0.163 & 0.072 & -2.300 & 0.023 \\
\hline
\end{tabular}

The extension professionals have to treat the technological information for easy understanding of the technologies. Besides, they have to use appropriate methods and other communication materials for effective transfer of technologies. But, poor performances of the extension professionals were observed on preparing teaching aids 
relevant to the area, putting thrust on motives of the non-responsive farmers, discussing with experts in formulating need based messages as well as preparing and distributing farm literatures for the reference of the farmers (Table-3). Hence; the extension professional should develop their technical competencies before transferring messages and strengthen all their communication approaches for effective technology transfer. However; better role performances were observed on providing spot solutions on field problems, keeping close contact with farm leaders for message transfer and giving wide publicity on implemented programmes that facilitate developing interest among farmers to adopt.

Planning is the decision making that involves in selecting and integrating various courses of action in order to attain the objectives. Good planning helps in effective transfer of technology and adoption of the suggested technologies. Better role performances were observed (Table-4) on selecting responsive farmers for field trial and demonstrations, participatory problem diagnosis and assessing interventions, pre-arrangements of inputs and materials as well as popularization of implements and machineries. Planning always emphasized for participatory programme development along with conservation of natural resources particularly soil and moisture. Poor performances observed on these aspects have to be given priority while making planning.

Planned programme have to be implemented timely and effectively ensuring productivity and profit. It has been observed from Table-5 that the respondents had comparatively better role performances on immediate action on field problems, involving farmers fully in implementation, timely use of inputs and materials as well as organising field days and method demonstration to enrich skill competency of the farmers. Poor performances were observed on economic use of natural resources, contingent measures in adverse situation and participatory evaluation of results that needs possible remedial measures from the farmer's perspective.

Transfer of technology aims to communicate the results of the research effectively for the development of the farmers. The farmers also need to be potential and capable enough for self-motivation and take rational decisions to adopt the technologies for which capacity building of the farmers is essential. But; poor performances of the extension professionals were observed(Table-6) towards organizing campaign on specific problems, exposure visit to develop confidence of farmers, organising exhibitions to expose farmers on latest developments, linking farmers with experts for solving queries and publication of farm literatures as reference materials. Considerable gaps were also observed on organising field days, documentation and evaluation of activities by the farmers. Though the respondents were organising training, all these approaches are to be further strengthened to develop the competency of the farmers.

Community organization is another important activity of the extension professionals in adoption of recommended practices. They have to organize farmers and form homogenous groups, facilitating conflict resolution, incorporating traditional wisdom of the farmers with the programmes implemented, liasoning with credit institutions for finance as well as farm mechanization through custom hiring service. But, poor performances were observed on these aspects (Table-7) which needs all possible remedial measures for effective dissemination of farm technologies. However, better performances were observed on motivating for cluster approach, guiding for 
commercial cultivation, income generating activities for resource poor and farm women as well as establishing cooperation and coordination among farming community.

Adoption of technologies will not be sustainable unless the produces are disposed easily and timely with remunerative price. Besides, quality production, value addition and proper storage are other considerations for easy disposal. But, the role performance of the respondents on these aspects were not satisfactory as observed (Table-8) except guiding for quality production. Deficiencies were observed on coordinating and liasoning with marketing organizations, liasoning with traders for timely procurement, liasoning with district authority for community storage, guiding producers in collecting market information as well as facilitating for proper storage and value addition particularly, cleaning, washing, grading etc. which are to be further strengthened for easy marketing of the produce with remunerative price.

Multiple regression analysis revealed (Table9) that the socio-economic attributes of the respondents had not much influence in accelerating their role performance. The best fitted regression equation could explain only $13.70 \%$ of the total variance in accelerating role performances of the respondents. However, service experience, age and training undertaken by the respondents had exhibited significant influence in accelerating their role performances.

In conclusion, agricultural extension service has a crucial role in increasing production and sustainable income to farming community. The performances of extension professionals are the key in the process of technology transfer and adoption by the farmers. The study conducted with 182 extension professionals in Odisha revealed that the respondents had good technical competency as well as better performances on communication system, planning, programme implementation as well as capacity building of the farmers. Satisfactory role performances were not observed on community organization and marketing of the produce. Liasoning for community storage, marketing organization and traders for timely procurement of the produce, preparing teaching aids while conducting training, organising campaign on specific problems, economic use of natural resources, exposure visit to develop confidence of the farmers, liasoning with credit institutions to finance farmers as well as organising farmers for effective technology transfer were some of the pertinent deficiencies observed in the role performance of the extension professionals. The extension professionals have to realize the essentialities of these deficiencies and put thrust on these aspects in performing better role performances resulting effective technology transfer and adoption by the farming community.

\section{References}

Copper, A.W. and Graham, D.L. (2001): Competencies needed to the successful country agents and country supervisors, Journal of Extension, 39(1): 333-343.

Linders, J.R. (2001): Competency assessment and human resource management performance of country extension chairs in Ohio, Journal of Agricultural Education, 24(4): 21-31.

Rabbe, K. (2008): Reforming the Agricultural extension system in India, IFPRI Discussion paper 00775, International Food Policy Research Institute, Washington D.C.

Swanson, B. (2008). The changing role of Agricultural extension in a global economy, Journal of International Agricultural and Extension Education, 10(1): 21-30. 
Tiraieyari, N., Idris, K., Uli, J., and Haunzah, A. (2011): Relationship between human development competencies and work performance, Australian Journal of Applied Science, 5(5): 1356-1363.

\section{How to cite this article:}

Behera, K.K. and Das, R.N. 2020. Role Performances of Agricultural Extension Professionals A Study in Odisha. Int.J.Curr.Microbiol.App.Sci. 9(08): 2110-2117. doi: https://doi.org/10.20546/ijcmas.2020.908.240 